\title{
The Effect of Intercellular Adhesion Molecule-1 Gene Polymorphism on Atherosclerosis in Patients with Glycogen Storage Disease Type 1
}

\section{Glikojen Depo Tip 1 Hastalarında Intersellüler Adezyon Molekülü Tip 1 Gen Polimorfizmin Ateroskleroza Etkisi}

\author{
Sema Kalkan Uçar1, Sezin Akman2, Afig Berdeli3, Mahmut Çoker1 \\ ${ }^{1}$ Ege University Faculty of Medicine, Department of Pediatrics, Division of Metabolism and Nutrition, Izmir, Turkey \\ 2Izmir Tepecik Training and Research Hospital, Clinic of Pediatrics, Izmir, Turkey \\ ${ }^{3}$ Ege University Faculty of Medicine, Pediatric Molecular Research Laboratory, Izmir, Turkey
}

\begin{abstract}
Aim: Glycogen storage disease type 1 is characterized with hypertriglyceridemia which does not lead to atherosclerosis. The human intercellular adhesion molecule-1 gene has been shown to be affected in atherosclerosis and postprandial hypertriglyceridemia.

Materials and Methods: In the present paper, the authors genotyped the Glu241Arg polymorphism in the intercellular adhesion molecule-1 gene in 35 patients with Glycogen storage disease type 1 and 108 healthy controls. Results: The results indicated a significant decrease in the frequency of the GG genotype in Glycogen storage disease type I patients compared to healthy controls. In addition, a significant correlation between the GG genotype and triglyceride levels was seen in Glycogen storage disease type 1 patients. Conclusion: It is thus concluded that the GG genotype could protect Glycogen storage disease type I patients from the development of atherosclerosis. The Journal of Pediatric Research 2015;2(1):7-10

Key Words: Glycogen storage disease type 1, intercellular adhesion
\end{abstract} molecule-1

Conflicts of Interest: The authors reported no conflict of interest related to this article.

\section{ÖZET}

Amaç: Glikojen depo hastalı̆ı tip 1'de görülen hipertrigliserideminin ateroskleroza yol açmadığı gösterilmiştir. Insan intersellüler adezyon molekülü tip 1'in ateroskleroz ve postprandial hipertrigliseridemi ile bağlantısı belgelenmiştir.

Gereç ve Yöntem: Sunulan çalışmada 35 glikojen depo hastalığı tip 1 hastanın ve 108 sağ|ıklı kontrol bireyin insan intersellüler adezyon molekülü tip 1 geni için Glu241Arg polimorfizm çalışması yapılmışıı.

Bulgular: Bulgularda GG genotipinde glikojen depo hastalığı tip 1 hastalarında sağıkıı kontrollere göre anlamlı bir yükseklik saptanmıştır. Ayrıca, GG genotipinin glikojen depo hastalı̆ıı tip 1 hastaların trigliserid düzeyleri ile arasında anlamlı korelasyon gözlenmiştir.

Sonuç: Bu veriler doğrultusunda glikojen depo hastalığı tip 1 hastalarında GG genotipin ateroskleroz açısından koruyucu olabileceği düşünülmüştür. The Journal of Pediatric Research 2015;2(1):7-10

Anahtar Kelimeler: Glikojen depo hastalı̆ı tip 1, intersellüler adezyon molekülü tip 1

Çıkar Çatışması: Yazarlar bu makale ile ilgili olarak herhangi bir çıkar çatışması bildirmemiştir. 


\section{Introduction}

Glycogen storage disease GSD type 1 (GSDI, von Gierke disease; OMIM p 232.200) is the most common type and is characterized by a deficiency of glucose-6-phosphatase/ transporter enzyme complex, which catalyzes the terminal step in both glycogenolysis and gluconeogenesis in the liver, kidney and small intestine (1).The main metabolic features of this disease are severe fasting hypoglycemia and marked hyperlipidemia, characterized by high triglycerides and total cholesterol with a low level of high-density lipoprotein. Despite the existence of longstanding dyslipidemia, it has been documented that GSDI is not associated with premature atherosclerosis (2-5). On the other hand, hyperlipemia has also been reported to be associated with increased levels of cellular adhesion molecules, particularly intercellular adhesion molecule-1 (ICAM-1) (6), and evidence also suggests that postprandial hyperlipemia may condition an increase of these molecules (7). Intercellular adhesion molecule-1 (ICAM-1, CD54) is a member of the immunoglobulin superfamily of adhesion molecules. It plays an important role in the adhesion of circulating leukocytes to the blood vessel wall and transendothelial migration to the vascular intima (8). Porsch-Oezçueruemez et al. (9) found that circulating ICAM could serve as a marker for atherosclerotic changes in the coronary system. Hajilooi et al. (10) showed that ICAM-1 values were significantly higher in patients with $C A D$ than in control participants. Furthermore, Poston et al. (11) reported that increased expression of ICAM-1 was detected in all subtypes of atherosclerotic lesions. Therefore, ICAM-1 might play an important role in the pathogenesis of atherosclerosis presented as coronary artery disease (12). The human ICAM1 gene is a single-copy gene on chromosome 19 and contains two polymorphic sites in codons 241 (G241R; Glu/Arg; exon 4) and 469 (K469E; Lys/Glu; exon 6) (13). ICAM-1 gene polymorphisms have been implicated in the susceptibility to a range of inflammatory diseases, including atherosclerosis and postprandial hypertriglyceridemia (14).

We hypothesized that genetic predisposition for up regulation of the expression of pro-inflammatory gene of ICAM-1 does not exist in patients with GSDI. Therefore, we investigated the Glu241Arg polymorphism in the ICAM-1 gene in patients with GSDI.

\section{Materials and Methods}

A total of 35 patients with GSDI and 108 healthy control subjects were enrolled into the study. GSDI diagnosed via enzymatic and genetic analysis, received a diet consisting of high carbohydrate intake, moderate fat and protein restriction (10). Exclusion criteria included endocrine, cardiovascular disorders, familial hyperlipidemia and use of medication. All GSD patients from our outpatient clinic were approached for participation and age-matched controls were taken after the selection of individual patients. The subjects of control group were recruited randomly from the department of Pediatrics.
Examinations were performed 3 to 8 hours after meals for GSD type 1, and after 8 to 10 hours fasting for controls. Written consent was obtained from the patients or parents. The study was approved by the local ethics committee and conducted in accordance with the guidelines in the Declaration of Helsinki.

Lipid profiles were determined by colorimetric test using standardized procedures. Germline DNA was extracted from peripheral blood by Qiagen MiniBlood Purification System kits. Amplification was carried out on a GeneAmp PCR System 9700. Controls of known genotype were included for every set of digestions carried out. Genotype was determined using appropriate restriction enzymes [BSrGI (Biolab)]. The G-A transition polymorphism in exon 4 was determined by PCR-RFLP method using the following primers: forward 5-CCGTGGTCTGTTCCCTGTAC-3'; reverse 5'-GAA GGAGTCGTTGCCATAGG-3' (Figure1).

\section{Statistical Analysis}

Statistical analysis was performed using the SPSS statistical package. The frequencies of the alleles and genotypes among the patient and control groups were determined and were then compared by $\chi^{2}$ test. A p value of $<0.05$ was accepted for statistical significance. Odds ratios (ORs) were calculated, together with their $95 \%$ confidence intervals (Cls).

\section{Results}

The basic characteristics and the fasting lipid profile of the patients enrolled into the study are summarized in Table I.

For the point mutation polymorphism located in ICAM-1 exon 4, which contains the information for codon 241, two alleles (i.e. allele $G$ and allele $A$ ) and different genotypes (i.e.homozygotes GG/AA or heterozygote GA) were present (Figure 1). Table II shows the allele and genotype frequencies of the G241R ICAM-1 gene polymorphism in 35 cases of GSDI and 108 controls. In both groups, there was a strong predominance of allele $\mathrm{G}$. Results have shown a significant decrease in A allele frequency $(\mathrm{OR}=0.8,95 \mathrm{Cl} \%$ 0.7-0.9, $\mathrm{p}=0.03$ ) and a significant increase in $\mathrm{GG}$ genotype ( $\mathrm{OR}=8.7$,

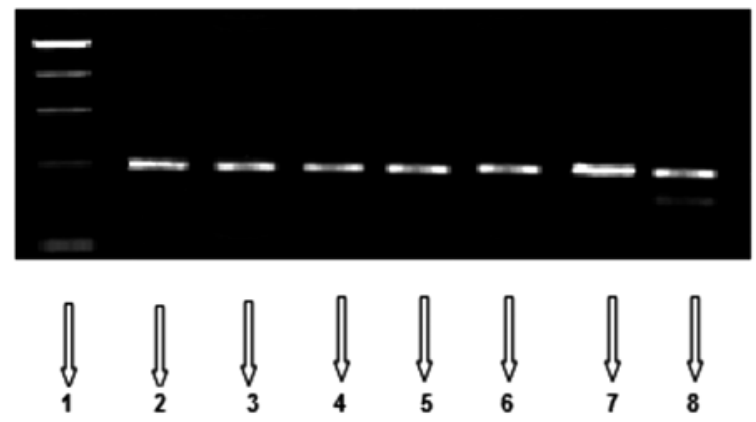

Line1 : 100bp DNAladder , Line2 : GG , Line3 : GG , Line4 : GG , Line5 : GG , Line6: GG , Line7 : GG , Line8 : GA

Figure 1. G/A genotyping by PCR-RFLP method using BSrGI (Biolab) restriction enzymes 


\begin{tabular}{|l|l|}
\hline \multicolumn{2}{|l|}{ Table I. Clinical and diagnostic characteristics of the patients with } \\
GSDI & $\begin{array}{l}\text { Numbers (\%) } \\
\text { / Mean } \pm \text { SD }\end{array}$ \\
\hline Parameters & 35 \\
\hline Number & $16 / 18$ \\
\hline Gender (male/female) & $7.2 \pm 5.6$ \\
\hline Age (years) & $31(88 \%)$ \\
\hline Consanguinity & $35(100 \%)$ \\
\hline Hepatomegaly & $30(85 \%)$ \\
\hline Hypoglycemia (blood level below 40 mg/dl) & $19(54 \%)$ \\
\hline Liver biopsy (Glycogen deposition) & $18(51 \%)$ \\
\hline Low enzyme activity (Glucose 6-phosphatase) & $35(100 \%)$ \\
\hline High biotinidase activity & $19(54 \%)$ \\
\hline $\begin{array}{l}\text { Homozygous/compound heterozygous (G6PC, } \\
\text { SLC37A4 gene) mutations }\end{array}$ & $204.5 \pm 61.5$ \\
\hline Total Cholesterol (mg/dl) & $345.3 \pm 36.6$ \\
\hline Triglyceride (mg/dl) & $43.0 \pm 18.3$ \\
\hline HDL-Cholesterol (mg/dl) & $101.1 \pm 54$ \\
\hline LDL-Cholesterol (mg/dl) & \\
\hline
\end{tabular}

Table II. Allele and genotype frequencies of G241R polymorphism in GSDI patients and controls

\begin{tabular}{|c|c|c|c|c|c|}
\hline Variable & GSD & & \multicolumn{2}{|l|}{ Controls } & p \\
\hline \multicolumn{6}{|c|}{ Allel } \\
\hline A & $1 / 70$ & $1.5 \%$ & $27 / 216$ & $12.5 \%$ & \multirow[t]{2}{*}{0.03} \\
\hline G & $69 / 70$ & $98.5 \%$ & $189 / 216$ & $87.5 \%$ & \\
\hline \multicolumn{6}{|c|}{ Genotype } \\
\hline AA & $0 / 35$ & $0 \%$ & $0 / 108$ & $0 \%$ & \multirow[t]{3}{*}{0.01} \\
\hline $\mathrm{GA}$ & $1 / 35$ & $2.9 \%$ & $27 / 108$ & $25 \%$ & \\
\hline GG & $34 / 35$ & $97.1 \%$ & $81 / 108$ & $75 \%$ & \\
\hline
\end{tabular}

$95 \mathrm{Cl} \% 1.2-62.1, \mathrm{p}=0.01)$ in GSDI patients compared to healthy controls. There was significant negative correlation between the ICAM genotype GG frequency in CSD group and triglyceride levels $(r=-3.36, p=0.00)$.

\section{Discussion}

Activation of the endothelium is a key event in the recruitment of cells of the immune system to the vessel wall. This requires the expression of adhesion molecules that play a key role in the development of atherosclerosis (15). Postprandial hypertriglyceridemia may represent an independent predictor of cardiovascular disease (1). Moreover, it has been shown that hypertriglyceridemia is associated with significant increase in ICAM levels (17). On the other hand, a considerable body of research undertaken in recent years has identified polymorphisms in many cytokine genes, especially within the upstream promoter sequences, which may be functionally relevant, because they may influence the levels of expression of these genes (18). Because inflammation is a consistent feature of atherosclerosis and it does not present in patients with GSDI despite their dyslipidemic status, we speculated that up regulation of ICAM-1, one of the important molecules in inflammation cascade does not occur. ICAM-1 is a protein with a core of $55 \mathrm{kDa}$ with five extracellular Ig-like domains $(8,19)$ coded by the second to the sixth exons. The human ICAM-1 gene is a single copy gene located on chromosome 19p13 and is known to contain at least two polymorphic sites, situated in codons 241 (G241R) and 469 (K469E) $(20,21)$. These two polymorphisms are single base mutations. At position 241, located in exon 4, the mutation GGG-AGG results in the exchange of glycine for arginine in the protein Ig-like domain 3 . Similarly, at position 469, located in exon 6, the mutation AAGGAG also leads to an amino acid change (lysine \pm glutamine) in the Ig-like domain 5 (22). In this preliminary study we found positive association between ICAM-1 G241R GG genotype frequency and patients with GSD. The G allele frequency was increased significantly in GSD groups compared to control group. This study suggests that absence of alterations in the amino acid sequences of the immunoglobulin like domains of ICAM-1 may prevent an influence of interactions with the respective ligands and, thus, the duration and/or intensity of the inflammatory reaction. The functional role of these point mutations might be related to the altered amino acid coding sequence. In this regard, it is noteworthy that the exon 4 mutation is located in the domain which has been shown to be of importance in binding to the Mac-1 form of the leukocyte integrin (19). The interaction between Mac-1 and ICAM-1 makes an important contribution to leukocyte adhesion in the execution of immunological and inflammatory functions and may play a role in regulating localization of leukocytes (23). The mutation of glycine with arginine in the third domain of ICAM-1 might affect the adhesive function of ICAM-1. Indeed, the common allele $G$, which encodes for glycine, is maintained in the analogous position in different species thus supporting the importance of this site for the control of ICAM1-mediated interactions (24). Therefore, it may contribute to the escape of hypertriglyceridemic patients with GSD I from atherosclerosis. Our study has several limitations. First of all, we did not measure serum ICAM-1 level. Secondly, the number of the patients is relatively small for a study aiming polymorphism analysis. Thirdly, we did not investigate the association between the ICAM-1 K469E polymorphism and atherosclerosis which might have been more informative.

In conclusion, this is the first report on the genetic reasons involved in the atherosclerotic escape of the dyslipidemic patients with GSDI. Further studies are required to investigate whether genetic factors determining the endothelial function in patients with GSDI are definitely responsible for the diminished pro-inflammatory and pro-atherogenic profiles.

\section{References}

1. Lei KJ, Shelly LL, Pan CJ, Sidbury JB, Chou JY. Mutations in the glucose-6-phosphatase gene that cause glycogen storage disease type 1a. Science 1993; 262: 580-3. 
2. Ubels FL, Rake JP, Slaets JPJ, Smit GPA, Smit AJ. Is glycogen storagedisease 1a associated with atherosclerosis? Eur J Pediatr 2002; 161 Suppl 1: S62-4.

3. Wittenstein $B$, Klein $M$, Finckh $B$, Ullrich $K$, Kohlschütter $A$. Plasmaantioxidants in pediatric patients with glycogenstorage disease, diabetes mellitus, and hypercholesterolemia. Free Radic Biol Med 2002; 33: 103-10.

4. den Hollander NC, Mulder DJ, Graaff R, Thorpe SR, Baynes JW, Smit GP, Smit AJ. Advanced glycation end products and the absence of premature atherosclerosis in glycogen storage disease la. J Inherit Metab Dis 2007; 30: 916-23.

5. Kalkan Ucar S, Coker M, Sözmen E, Goksen Simsek D, Darcan S. "A monocentric pilot study of an antioxidative defense and hsCRP in pediatric patients with glycogen storage disease type IA and III." Nutr Metab Cardiovasc Dis 2009; 19: 383-90.

6. Hackman A, Abe Y, Insull W Jr, Pownall H, Smith L, Dunn K, Gotto AM Jr, Ballantyne CM. Levels of soluble cell adhesion molecules in patients with dyslipidemia. Circulation 1996; 93: 1334-8.

7. Nappo F, Esposito K, Cioffi M, Giugliano G, Molinari AM, Paolisso G, Marfella R, Giugliano D. Postprandial endothelial activation in healthy subjects and in type 2 diabetic patients: role of fat and carbohydrate meals. J Am Coll Cardiol 2002; 39: 1145-50

8. Hayflick JS, Kilgannon $\mathrm{P}$, Gallatin WM. The intercellular adhesion molecule (ICAM) family of proteins. New members and novel functions. Immunol Res1998; 17: 313-27.

9. Porsch-Oezçueruemez M, Kunz D, Kloer HU, Luley C Evaluation of serum levels of solubilized adhesion molecules and cytokine receptors in coronary heart disease. J Am Coll Cardiol 1999; 34: 1995-2001.

10. Hajilooi M, Sanati A, Ahmadieh A, Ghofraniha A, Massoud A. Circulating ICAM-1, VCAM-1, E-selectin, P-selectin, and TNFalphaRII in patients with coronary artery disease. Immunol Invest 2003; 32: 245-57.

11. Poston RN, Haskard DO, Coucher JR, Gall NP, JohnsonTidey RR. Expression of intercellular adhesion molecule-1 in atherosclerotic plaques. Am J Pathol 1992; 140: 665-73.
12. Li D, Qu C, Dong P. The ICAM-1 K469E polymorphism is associated with the risk of coronary artery disease: a metaanalysis. Coron Artery Dis 2014; 25: 665-70.

13. Wawryk SO, Cockerill PN, Wicks IP, Boyd AW. Isolation and characterization of the promoter region of the human intercellular adhesion molecule-1 gene. Int Immunol 1991; 3: 83-93.

14. Norata GD, Grigore L, Raselli S, Redaelli L, Hamsten A, Maggi $F_{i}$ Eriksson P, Catapano AL. Post-prandial endothelial dysfunction in hypertriglyceridemic subjects: molecular mechanisms and gene expression studies. Atherosclerosis 2007; 193: 321-7.

15. Hansson GK. Inflammation, atherosclerosis, and coronary artery disease. N Engl J Med 2005; 352: 1685-95.

16. Ebenbichler CF, Kirchmair R, Egger C, Patsch JR. Postprandial state and atherosclerosis. Curr Opin Lipidol 1995; 6: 286-90.

17. Benítez MB, Cuniberti L, Fornari MC, Gomez Rosso L, Berardi V, Elikir G, Stutzbach P, Schreier L, Wikinski R, Brites F. Endothelial and leukocyte adhesion molecules in primary hypertriglyceridemia. Atherosclerosis 2008; 197: 679-87.

18. Bidwell J, Keen L, Gallagher G. Cytokine gene polymorphism in human disease: on-line databases. Genes Immun 1999; 1: 3-19.

19. Diamond MS, Staunton DE, Marlin SD, Springer TA Binding of the integrin Mac-1 (CD11b/CD18) to the third immunoglobulin-like domain of ICAM-1 (CD54) and its regulation by glycosylation. Cell 1991; 65: 961-71.

20. Vora DK, Rosenbloom CL, Beaudet AL, Cottingham RW Polymorphisms and linkage analysis for ICAM-1 and the selectin gene cluster. Genomics 1994; 21: 473-477.

21. Wenzel K, Ernst M, Rohde K, Baumann G, Speer A. DNA polymorphisms in adhesion molecule genes a new risk factor for early athersclerosis. Hum Genet 1996; 97: 15-20.

22. Macchioni P, Boiardi L, Casali B, Nicoli D, Farnetti E, Salvarani C. Intercellular adhesion molecule 1 (ICAM-1) gene polymorphisms in Italian patients with rheumatoid arthitis. Clin Exp Rheumatol 2000; 18: 553-8.

23. van de Stolpe A, van der Saag PT. Intercellular adhesion molecule-1. J Mol Med (Berl) 1996; 74: 13-33.

24. Yang $H$, Analysis of ICAM-1 gene polymorphism in immunologic subsets of in־ammatory bowel disease. Exp Clin Immunogenet 1997; 14: 214-25. 